Volume 2

Number 2 Teaching Secrecy

January 2021

\title{
Today's Fake News is Tomorrow's Fake History: How US History Textbooks Mirror Corporate News Media Narratives
}

\author{
Nolan Higdon \\ CSU East Bay, nolanrhigdon@gmail.com \\ Mickey Huff \\ Diablo Valley College, mhuff@dvc.edu \\ Jen Lyons \\ Independent Researcher, jenlyons@nevada.unr.edu
}

Follow this and additional works at: https://scholarworks.sjsu.edu/secrecyandsociety

Part of the Critical and Cultural Studies Commons, Curriculum and Social Inquiry Commons, Military History Commons, Social Influence and Political Communication Commons, and the Teacher Education and Professional Development Commons

\section{Recommended Citation}

Higdon, Nolan; Mickey Huff; and Jen Lyons. 2021. "Today's Fake News is Tomorrow's Fake History: How US History Textbooks Mirror Corporate News Media Narratives." Secrecy and Society 2(2). https://doi.org/10.31979/2377-6188.2021.020204

https://scholarworks.sjsu.edu/secrecyandsociety/vol2/iss2/4

This Special Issue Article is brought to you for free and open access by the School of Information at SJSU ScholarWorks. It has been accepted for inclusion in Secrecy and Society by an authorized administrator of SJSU ScholarWorks. For more information, please contact scholarworks@sjsu.edu. 


\title{
Today's Fake News is Tomorrow's Fake History: How US History Textbooks Mirror Corporate News Media Narratives
}

\author{
Abstract \\ The main thrust of this study is to assess how the systematic biases found in mass media \\ journalism affect the writing of history textbooks. There has been little attention paid to \\ how the dissemination of select news information regarding the recent past, particularly \\ from the 1990s through the War on Terror, influences the ways in which US history is \\ taught in schools. This study employs a critical-historical lens with a media ecology \\ framework to compare Project Censored's annual list of censored and under-reported \\ stories to the leading and most adopted high school and college US history textbooks. The \\ findings reveal that historical narratives largely mirror corporate media reporting, while \\ countervailing investigative journalism is often missing from the textbooks. This study \\ demonstrates the need for critical media literacy inside the pedagogy of history education \\ and teacher training programs in the US.
}

\section{Keywords}

Noam Chomsky, censorship, contemporary historiography, critical media literacy, fake news, Edward Herman, James Loewen, human rights, journalism, media ecology, propaganda, Propaganda Model, Project Censored, secrecy, teaching, textbooks, US history, War on Terror

\section{Cover Page Footnote}

The authors would like to acknowledge research assistance from Matthew Phillips, a former journalism student at Taylor University and intern with Project Censored. 


\title{
Today's Fake News is Tomorrow's Fake History: How US History Textbooks Mirror Corporate News Media Narratives
}

Nolan Higdon, Mickey Huff, and Jen Lyons ${ }^{1}$

\begin{abstract}
The main thrust of this study is to assess how the systematic biases found in mass media journalism affect the writing of history textbooks. There has been little attention paid to how the dissemination of select news information regarding the recent past, particularly from the 1990s through the War on Terror, influences the ways in which US history is taught in schools. This study employs a critical-historical lens with a media ecology framework to compare Project Censored's annual list of censored and under-reported stories to the leading and most adopted high school and college US history textbooks. The findings reveal that historical narratives largely mirror corporate media reporting, while countervailing investigative journalism is often missing from the textbooks. This study demonstrates the need for critical media literacy inside the pedagogy of history education and teacher training programs in the US.
\end{abstract}

\section{Keywords}

Noam Chomsky, censorship, contemporary historiography, critical media literacy, fake news, Edward Herman, James Loewen, human rights, journalism, media ecology, propaganda, Propaganda Model, Project Censored, secrecy, teaching, textbooks, US history, War on Terror

"Our war on terror begins with al Qaeda, but it does not end there. It will not end until every terrorist group of global reach has been found, stopped and defeated" declared then President George W. Bush September 20, 2001. ${ }^{1}$ Bush's proclamation, just over a week after the events of

1 Nolan Higdon is a lecturer in History and Media Studies at California State University, East Bay; Mickey Huff is director of Project Censored and professor of Social Science and History, Diablo Valley College; Jen Lyons' holds an MA in history. Her Master's Thesis, Weapons of Mass Persuasion: The Overlap of Public Propaganda and Private Magazine Advertisements in the World War II Era was completed in 2020. 
Secrecy and Society, Vol. 2, No. 2 [2021], Art. 4

September 11, 2001, described what would be known as the War on Terror, a war that saw ground troops in Afghanistan, Iraq, and Syria as well as drone strikes and cyberwarfare, which impacted millions of people around the globe.

Scholars have documented that the US government considers secrecy as paramount to achieving strategic goals in the War on Terror. ${ }^{2}$ They cite the federal government's efforts to silence whistleblowers - such as Chelsea Manning, and National Security Administration contractor Edward Snowdenand those who publish the disclosures from whistleblowers - such as Julian Assange of WikiLeaks - from exposing the federal government's behaviors and attitudes during the War on Terror. ${ }^{3}$ Susan Maret and Jan Goldman's Government Secrecy: Classic and Contemporary Readings chronicled the rise of government secrecy, national security, and the war on terror ${ }^{4}$; Matthew Potolsky's The National Security Sublime: On the Aesthetics of Government Secrecy points out that US citizens' limited knowledge about the national security state derives from whistleblowers, news reports, and declassified or leaked governmental documents. ${ }^{5}$

Media scholars note that with little available evidence of the war's efficacy, public support for the War on Terror is maintained in-part through traditional news media (also referred to as corporate or establishment media) reporting. ${ }^{6}$ Most famously, The New York Times' Judith Miller provided convincing, albeit false, reporting that gave justification for the US invasion of Iraq in 2003. Miller relied on sources in the Pentagon and 
Higdon et al:: Today's Fake News is Tomorrow's Fake History

intelligence community, both of which were advocating for a US invasion of

Iraq at the time, to claim that Iraq was procuring what were known as weapons of mass destruction (WMDs). ${ }^{7}$ Her reporting was seen as vital for advancing public support for the US to invade Iraq, in order stop WMD production.

As David Barstow of the same New York Times pointed out five years later, winning a Pulitzer Prize in the process, that since 2002 the Pentagon military analyst program had been propping up retired generals and active security agents in the corporate press to further their messaging. The goal was to have these individuals, whose affiliations with the military and intelligence community were rarely mentioned if at all, shape the electorate's understanding of foreign policy. In fact, Barstow explained that "some analysts stated that in later interviews that they echoed the Pentagon's talking points, even when they suspected the information was false or inflated." 8

Scholars such American sociologists C. Wright Mills and William Domhoff, political sociologist Peter Phillips, the late political economist Edward Herman, and linguist Noam Chomsky have long noted the ways in which the elite consensus in government is disseminated to the American public as "objective" journalism. There are other hidden factors overlooked as historical catalysts by establishment reporting as well, including "blowback," a CIA term that describes unintended consequences of covert operations, is rarely mentioned as a possible explanation for events in 
Secrecy and Society, Vol. 2, No. 2 [2021], Art. 4

historical records. Scholar Chalmers Johnson wrote a trilogy on the matter, particularly reflecting on the events of September 11th, 2001, but also more broadly calling out US policy throughout the Cold War where blowback was a significant factor in political developments. That this information is rarely if ever noted in the most adopted major historical textbooks for courses in US colleges is noteworthy. ${ }^{9}$ One longtime CIA analyst and whistleblower, Ralph McGehee, went further when he noted the agency's efforts to manipulate information in the press, which would become part of official historical narrative regarding US policy, stating "yesterday's fake news, tomorrow's fake history."10

Although this persists through the War on Terror, propaganda and fake news production goes beyond an elite cabal of government and industry leaders to include some members of the press, governments around the world, political parties, and satirists, among others. In The Anatomy of Fake News: A Critical News Literacy Education, Nolan Higdon defines fake news as "false or misleading content presented as news."11 Fake news can be propaganda, which scholar Nancy Snow defines as "information campaign of lies and deceptions to benefit the sponsoring institution."12 Furthermore, the production, dissemination, and influence of fake news have been complicated by the advent of the Internet. ${ }^{13}$ The Internet allows users to reach global audiences, and its algorithmic analysis of data allows for fake news content to be created and disseminated with effective microtargeting strategies by parties with the ability to reach increasingly broad 
Higdon et al.: Today's Fake News is Tomorrow's Fake History

demographics for their own potential gains. ${ }^{14} \mathrm{~A}$ litany of recent scholarship

has demonstrated many media users struggle to delineate fake news from legitimate journalistic content. ${ }^{15}$ However, it is not known what impact this has, if any, on the production of historical texts.

\section{History}

History is the "branch of knowledge that deals with human past...history may be defined as events of human life."16 Professionally, historians are entrusted with keeping a record of events and processes that contextualize the present and inform our expectations of the future. Until the 19th century, what was considered history in the US was generally contemporary history. Indeed, those privileged with time and skills to write would draft texts that were considered history. In the 19th century, changes to education allowed for the professionalization of the field. ${ }^{17}$ Until the 1960 s, contemporary history was viewed as inappropriate for scholars to study because they were too close to the topic and thus considered unable to offer objective analysis. In the 1960 s, thanks in large part to Geoffrey Barraclough's seminal book An Introduction to Contemporary History, contemporary history grew into favor. ${ }^{18}$

One type of source historians rely upon is journalism, also known as "the news," which was once referred to by Phillip Graham, publisher of the Washington Post, as "the first rough draft of history."19 However, since the 1960s, some historians have remained resistant to the use of current news media in their research. For example, in 1967, historian Arthur Schlesinger 
Secrecy and Society, Vol. 2, No. 2 [2021], Art. 4

not only wrote about his opposition to historians discussing current events, but even in engaging with contemporary texts, arguing that "the growing insistence that official papers should, as a matter of right, be immediately opened to scholars leads to a dilution and distortion of the written record."20 This ethos has defined the field. In the History Manifesto, Jo Guldi and David Armitage argue that historians are largely unwilling to engage in contemporary discourse and issues, preferring narrow fields of study about the past, because they believe it will compromise the field of history if they engage in current, non-academic publishing. ${ }^{21}$ In 2012, Oxford historian Sir Keith Thomas warned that a "parasitic" relationship was being created between young historians who engaged with commercially viable contemporary issues and the field of history. ${ }^{22}$

For historians who utilize journalistic outlets among their sources, the media ecosystem has only become more complex since the $1960 \mathrm{~s}$. This has become possible through the advent of 24-hour news networks, the Internet, and eventually, social media, along with other new platforms for news dissemination such as podcasting. ${ }^{23}$ Few schools in the US provide news literacy curriculum for students, and there is no indication history programs train scholars to adapt their research methods to the rapidly changing media landscape. ${ }^{24}$

Note that determining the veracity of news and information goes beyond making lists of trustworthy and non-trustworthy sources. Even trusted news outlets with a long history of accurate reporting can fabricate 
Higdon et al.: Today's Fake News is Tomorrow's Fake History

evidence or rely on problematic sources. ${ }^{25}$ For example, the New York Times, the often referred to "paper of record," published Judith Miller's bogus pieces on alleged weapons of mass destruction in Iraq as well as Jayson Blair's numerous fabricated stories. ${ }^{26}$ Furthermore, traditional methods of verifying sources through multiple outlets is also problematic, given the ways in which the Internet allows false information to not only be reproduced and packaged quickly, but sent repetitiously to users who conflate familiarity with veracity. ${ }^{27}$ Given the pervasive influence of fake news and concerns around it, it is crucial to consider whether today's fake news could become tomorrow's fake history.

\section{Methodology}

This study employs a critical-historical lens of the 21 st century news media ecosystem to compare the similarities and differences regarding US news coverage and college history textbooks key issues from the 1990s and the War on Terror. Like any other message, the news is given power and meaning through the communicative process. ${ }^{28}$ Media ecology theory argues that we can understand that process through an examination of the relationship between technology, communication, media and its impact on the human environment. ${ }^{29}$ Media ecology scholars value "networks of relations (ecosystems) rather than individual essences and processes rather than entities." ${ }^{\prime 30}$ This study examines the network of relations and processes by which news is produced, disseminated, and legitimized to see if that 
Secrecy and Society, Vol. 2, No. 2 [2021], Art. 4

process influences the production of history. Media ecology scholars argue

that the complex and changing relationships and processes that comprise a media ecosystem are best understood through an historical lens of the media environment. ${ }^{31}$ As a result, this study analyzed the technological, communication, media, and human influences associated with censorship, fake news, and propaganda from a critical-historical lens.

Our analysis follows the tradition of media ecology scholars who integrated the critical framework of the Frankfurt and Birmingham School into their analysis. ${ }^{32}$ Critical communication theory posits that dominant ideologies result from power inequities that are strengthened and fortified through media and communication. ${ }^{33}$ They contend that liberation from dominant ideologies is possible through a critical examination of media and power. ${ }^{34}$ As a result, this study critically analyzes the power dynamics associated with the production, purpose, and themes of news in the hopes that critical media literacy scholars can synthesize them into pedagogy of resistance and liberation from corporate and establishment dominant narrative histories.

The data for this study derives from two sources: Project Censored's annual under-reported news story lists and the most widely adopted US history college textbooks. Project Censored's critical, theoretical and analytical framework for understanding modern media censorship, dating back to 1976, posits that the funding models behind news organizations influence the type of content they produce based on the Propaganda Model 
Higdon et al.: Today's Fake News is Tomorrow's Fake History

of News put forth by Herman and Chomsky in 1988. Herman and Chomsky

conclude that corporate news media producers' ideology and profit shape

their editorial decisions. Given the sheer influence of these media

corporations, six of which now control 90 percent of the news media in the

US, Project Censored finds that the news content these outlets ignore,

under-represent, or misrepresent is a form of censorship. Each year Project

Censored researchers identify and vet critical news stories that have not

been covered by the corporate media. The top 25 censored news stories are selected by faculty, students, and panel of expert judges to be featured in the annual issue. ${ }^{35}$

The authors do not assume that every article in the alternative press is accurate, but the one's published by Project Censored have undergone a review by faculty and area experts as well as research students and finally by their team of expert judges, which is a testament to their veracity. Since the War on Terror began, over 400 news articles have been vetted and republished by Project Censored around key issues in US society, many of which were about foreign policy, and they were all analyzed for this study.

Our study sought to examine if historians adopt or research beyond the corporate press narratives about the War on Terror. We compared the scholarship found in the most widely adopted US history textbooks with Project Censored's annual list of the top censored stories. Our methodological framework is based on historian and sociologist James Loewen's Lies My Teacher Told Me: Everything Your American History 
Secrecy and Society, Vol. 2, No. 2 [2021], Art. 4

Textbook Got Wrong (from 1995, republished in 2008, and updated in

2018), where the sociologist reviewed the most widely adopted history

textbooks in US colleges to identify historical inaccuracies. ${ }^{36}$ We determined

these texts by consulting the American Textbook Council's "Widely Adopted

History Textbooks," which has been tracking sales since $1986 .{ }^{37}$ Their most

recent sales numbers come from 2018. We chose to examine the top five

textbooks, which include:

\section{Author}

Alan Brinkley, Andrew Huebner and John Giggie

Robert A. Divine, T. H. Breen, R. Hal Williams, Ariela J. Gross, and H.W. Brands

John Mack Faragher, Mari Jo Buhle, Daniel H. Czitrom, and Susan $\mathrm{H}$. Armitage

James A. Henretta, Eric Hinderaker, Rebecca Edwards, and Robert 0. Self

David M. Kennedy and Lizabeth Cohen
Title

The Unfinished Nation: A Concise History of the American People

America Past and Present (vol. 1)

Out of Many: History of the American People

America's History (vol.1)

The American Pageant: A History of the American People
Bedford/Macmillan (2017)

\section{Publisher}

McGraw Hill (2018)

Prentice Hall (2012)

Prentice Hall

(2015)

Houghton

Mifflin/Cengage

(2019) 
As we surveyed these textbooks and compared them to the lists in Project Censored's top censored stories, we performed two rounds of coding. We chose to look at news stories regarding foreign policy and terrorism since the 1990s. The first round of coding looked for the stories from the independent press that were absent in establishment media and the textbooks as well the corporate news narratives that appeared in historical textbooks. The second round of coding put the various stories into thematic categories.

\section{Findings}

In nearly all of the cases, with Out of Many often as an exception, the history textbook narratives matched that of the corporate press. Our research revealed four themes in the history textbooks. First, details regarding US imperialism are missing from the textbooks through the process of ignoring most of the US presence and action around the globe, especially in pursuit of natural resources and geostrategic locations. Second, foreign lives are treated as unimportant and essentially supporting actors in an American story. Third, the president is respected for success as a Commander-in-Chief, but failures are concealed or rationalized. Lastly, the United States is treated as the victim and not the aggressor in most foreign policy narratives. Below we expand on these themes.

\section{Oil and Imperialism}


Secrecy and Society, Vol. 2, No. 2 [2021], Art. 4

From threats of colonialism, US invasion, potential economic crises, and the billions of dollars spent on US occupation in the Middle East, conflict over oil is both complicated and central to American foreign policy. This is made clear by independent press outlets, but not in the corporate press. Perhaps, consequently, the history textbooks we reviewed mostly downplay the role that oil interests play in shaping America's foreign policy. When the influence of oil on foreign policy is discussed, it is treated as a political interpretation rather than a documented fact.

Especially relevant during George W. Bush's tenure as president, issues surrounding oil were overlooked with reports of potential terrorism from the same region. Although President Bush claimed his top foreign policy priority was to prevent terrorism and curb the spread of weapons of mass destruction outside of the United States, it has been revealed that the president's first concern was really to "increase the flow of petroleum from suppliers abroad to US markets," due to a severe oil and natural gas shortage throughout the United States. ${ }^{38}$ Bush and his Vice President Dick Cheney came from the oil industry, a fact that was typically ignored by the corporate media. Instead, the corporate press fixated on concerns over terrorism which concealed the growing conflict surrounding oil and other foreign natural resources.

The history textbooks either dismissed the topic of fossil fuels or discussed them in a way that was unrelated to foreign policy. One exception was Unfinished Nation, which discusses the topic of oil and foreign policy. 
Higdon et al.: Today's Fake News is Tomorrow's Fake History

However, rather than investigate the role that oil plays in American foreign

policy, it introduces it as a matter competing interpretations between the politically right and left. The text summarizes the position that oil interests drive foreign policy is a left critique, not necessarily a position supported by facts. However, oil's central role in American foreign policy is well documented. Where the influence of oil in fostering war is ignored history texts, so too is the impact war has on non-Americans.

\section{Foreign Lives Do Not Matter}

Although the impact of war on American lives is readily covered in socalled mainstream media, the human rights abuses and murder of non-US citizens received little if any corporate coverage. This is also the case in the most widely adopted textbooks when it comes to torture and death. In fact, the soft coverage is not only limited to the US, but its NATO allies as well.

The corporate press has largely ignored the human rights abuses suffered by non-Americans during the War on Terror. Even when the most widely known establishment press outlets do report on human rights abuses, they tend to downplay or dismiss crucial information. During President Barack Obama's Administration, investigative journalist Nafeez Ahmed reported that corporate coverage concerning CIA abductions and interrogations of terrorism suspects "whitewashed the extent to which torture has always been an integral and systemic intelligence practice since the second World War." 39 Essentially, the traditional corporate media outlets reiterate sugar-coated information provided by government officials that 
Secrecy and Society, Vol. 2, No. 2 [2021], Art. 4

masks the thousands of people who were kidnapped and tortured. ${ }^{40}$

The majority of textbooks analyzed in this study ignore the issue of torture, except to note the highly publicized cases at Abu Ghraib prison in Iraq and the US detention center at Guantanamo Bay. However, most of the texts ignore the number of victims; the process of kidnapping known as "extraordinary renditions" (abductions); and the centrality of "enhanced interrogation techniques" (torture), as part of US foreign policy. Rather these are only mentioned as potential aberrations, not a central part of the policy, which they were. Out of Many was more forthcoming about US foreign policy. It mentioned enhanced interrogation techniques, including sleep deprivation, sensory deprivation, and waterboarding, at Guantanamo, and also at CIA "black sites," secret jails overseas. The only other mention of waterboarding in the texts came from President Obama who issued an executive order banning the practice. The texts did not go into any detail of how it was used under the previous administration of George W. Bush, for how long, or to what end. Similar to torture, the corporate press avoids coverage of the non-US casualties of war.

The research shows that corporate media outlets avoid reporting on intentional destruction caused by US military and their weapons, threats of modern forms of colonialism, economic censorship, and US imposed methods of torture throughout the Middle East. Several Project Censored reports reveal the realities imposed by United States entry into the Middle East, including the over one million Iraqi deaths that have been caused by 
Higdon et al.: Today's Fake News is Tomorrow's Fake History

US occupation since $2003 .{ }^{41}$ The United States occupancy has resulted in unbelievable human destruction since the early 2000s; according to a series of face-to-face interviews with 2,414 Iraqi adults, the findings concluded that "more than one in five respondents had had at least one death in their household as a result of the conflict." ${ }^{22}$ Corporate media has continued to avoid reporting these numbers.

The loss of human life is as invisible in textbooks as it is in news media reporting. Information regarding the loss of human lives in major events such as the 2003 US invasion of Iraq were mostly limited to US soldiers. Some of the texts did note the death of Iraqis, but others such as Out of Many tallied them in the thousands rather than the conservative estimate of hundreds of thousands, let alone millions as has been documented by numerous reputable sources across the globe. For example, regarding the 2003 invasion of Iraq, which followed the 1991 bombardment and invasion, American Pageant's only mention of Iraqi casualties is in the context of US/Russian entanglements with ISIS and Syria between 2011 and 2014 involving a "civil war." This is where the text states that half a million Iraqis and Syrians "lay dead." Given the likelihood of over 1 million dead by 2008, with over 5 million refugees from Iraq alone, it is under-counting and misleading to place these deaths in the context of yet another conflict in the Middle East. The text mentions "inner fighting" in Iraq as a result of the invasion, but even under the Obama years, there is no further mention of the human cost of war, regardless of side. Worse, rather than deconstruct 
Secrecy and Society, Vol. 2, No. 2 [2021], Art. 4

the bellicose language of the US toward Iraq, American Pageant engaged in it as they discussed Desert Storm as having light US casualties with heavy Iraqi damage under a subtitle "Owning Iraq."

The research from Project Censored demonstrated that the North Atlantic Treaty Organization (NATO) often conceals it bellicose language and militaristic behavior behind soft language about peace. They found that in general, NATO, the world's largest political and military alliance, remains under-reported on by corporate and independent media outlets. When the establishment press does cover issues regarding NATO, it typically avoids stories that outline violence committed by NATO members - especially in regard to the United States. In the late 1990s, for example, the United States and NATO pushed for war in Yugoslavia "by demanding full military occupation of the entire country as a condition of not bombing." 43 This blatantly violent "condition" received little news coverage by the corporate press, due to the fact it would cause controversy regarding US decisionmakers within the NATO alliance. The result is waning discourse about the pernicious influence and impact that NATO has on the lives of people around the globe.

The soft rhetoric on NATO and its invisibility in the corporate press is mirrored in the historical texts. For example, American Pageant discusses NATO through the text as a "peacekeeper" without discussing the violence in many of NATO's affairs, including their involvement in Yugoslavia. The text did address NATO expansion in the post-cold war period by adding member 
Higdon et al.: Today's Fake News is Tomorrow's Fake History

states, but they do not explain this in global context, especially as a driver of ongoing conflicts regarding the former Soviet Union, or Russia, which to this day is a central nemesis in US politics. Similarly, Unfinished Nation has limited mention of NATO around Yugoslavia, and NATO "peacekeeping forces." Lastly, America: Past and Present noted "the Clinton administration backed Yeltsin and his successor, Vladimir V. Putin, despite Russia's continuing brutal war with Chechnya. Although the expansion of NATO to include Poland, Hungary, and the Czech Republic, and plans for a missile defense system created some tension, the Clinton administration succeeded in maintaining good relations with Russia...." Even if the atrocities and human rights abuses against individuals around the globe are covered, it becomes clear that the president, as commander in chief, is not responsible.

\section{The Commander in Chief is Not Responsible}

A historic amount of corporate media coverage has been paid to the events, victims, and devastation that took place on September 11, 2001. However, interestingly, Project Censored revealed that in the War on Terror, the corporate press tended to cover perceived presidential successes favorably, while dismissing or ignoring failure. For example, the CIA issued multiple warnings to President Bush regarding a potential terrorist attack prior to September 11, 2001. Beginning in spring of 2001, "the CIA 'repeatedly and urgently' warned the White House that an attack was imminent." 44 However, the White House responded to the warning with 
Secrecy and Society, Vol. 2, No. 2 [2021], Art. 4

"we're not quite ready to consider this. We don't want to start the clock

ticking."45 This nonchalant response by government leaders was ignored by corporate media, drowned out with repetitive stories depicting the devastation that was enabled by the choice by the country's highest leaders to remain ignorant.

Just like the corporate press, the historical texts did not introduce the myriad pre-warnings. Again, the one exception is Out of Many, which does mention numerous pre-warnings in the context of the 9/11 attacks.

Meanwhile, Unfinished Nation not only ignores the documented pre-warnings regarding the 9/11 attacks, but the role of the CIA in the post-Cold War. The only mention they receive is in regard to the revelations by Snowden. It is also interesting that a text such as American Pageant will not use space in its text to document Bush's failed response to the multiple warnings.

Throughout President Obama's administration, corporate media outlets tended to cover domestic issues and foreign policy success while discounting a number of stories, including inhumane treatment along the US-Mexico border, economic controversy surrounding potential global plans to replace the dollar, and military secrecy over an expansive budget, acts of torture, and drones. Although he promised to slash government expenses, President Obama approved an increase in military spending while also allowing a cut in the domestic budget, resulting in "the greatest administrative military spending since World War II."46 Several independent reports cited by Project Censored noted "there is widespread and continuous waste, fraud, and 
Higdon et al.: Today's Fake News is Tomorrow's Fake History abuse by the Pentagon and by military contractors resulting in welfare for the rich...the public never hears about war spending in the corporate media and how much everything actually costs. ${ }^{\prime 47}$ While this economic mishap has not been typically covered by corporate media nor textbook authors, the most shocking under-reported detail is that by 2016, the US government had accumulated $\$ 6.5$ trillion in military expenditures that cannot be accounted for even after auditing. ${ }^{48}$

Once again, the textbook narratives largely mirrored the coverage of the corporate press in that they had almost no discussion of these topics. However, one exception is immigration which Out of Many covered. America: Past and Present also covered immigration as an issue for Obama. However, in all cases, the texts remains devoid of any discussion about the human rights abuses at the border or the larger context of how the US foreign policy of presidents in both the recent and distance past have shaped immigration.

\section{US Relations Around the Globe}

Collectively, the foreign policy stories in Project Censored reveal the imperialist nature of the US. The corporate press in the US generally ignore the presence of the US military around globe. Instead, they focus on a narrow scope of nations such as Afghanistan, Iraq, Iran, North Korea, and Syria. Meanwhile the US presence elsewhere is rarely covered. For example, the corporate press avoids covering American leaders that have been caught lying about issues in Asia, concealing details of bombings and destruction 
Secrecy and Society, Vol. 2, No. 2 [2021], Art. 4

inflicted by the United States military, and twisting other realities to portray the United States positively. In 2004, following a historically devastating tsunami in Southeast Asia, the corporate and independent media essentially ignored the United States pursuit to extort the extensive destruction to their advantage. The domestic corporate media reported extensively on US aid to Southeast Asia, while completely ignoring simultaneous military motives and expansion throughout the same region. One independent report noted "at the same time that US aid was widely publicized domestically, our coinciding military motives were virtually ignored by the press. While supplying our aid (which when compared proportionately to that of other, less wealthy countries, was an insulting pittance), we simultaneously bolstered military alliances with regional powers in, and began expanding our bases throughout, the Indian Ocean region." ${ }^{\prime 9}$ The examination of stories overlooked by establishment media regarding issues in Asia mostly ignore the wrong doings of United States leaders and instead glorify any slight effort to improve circumstances.

Similarly, in Central and South America, the corporate media tend to frame American leaders and decision makers as philanthropists promoting the greater good of humanity, while ignoring the mass killings and destructive trade agreements inflicted throughout the region. In fact, the United States uses Latin American military bases to expand control over the region. While United States leaders proclaim these military bases located throughout Latin America aim to help others, nearby citizens argue that the 
Higdon et al.: Today's Fake News is Tomorrow's Fake History

bases are actually "part of a broader imperialist strategy aimed at exploiting the continent's natural resources [and] suppressing popular movements."50 This attempted expansion of control within Central and South America has resulted in disaster throughout the region, including the vast elimination of crops through the use of chemicals deemed illegal in the United States. ${ }^{51}$ Destruction of physical and economic resources throughout Central and South America do not fit corporate media protocol, and remain underreported throughout the press in the United States.

In Africa, the corporate press refuses to cover US foreign policy even though it is colliding with China's foreign policy aims. As a world leader, the United States regularly participates in acts of colonialism, efforts to gain control of resources, and serious war crimes throughout many parts of Africa. In recent years, the United States has been regularly competing with China to dominate political and economic leverage within Africa, which has led to further conflict throughout the resource-rich continent. ${ }^{52}$ This has led to additional US military presence and penetration throughout much of the African continent, which has been "presented as a humanitarian guard in the Global War on Terror. The real objective is, however, the procurement and control of Africa's oil and its global delivery systems." ${ }^{53}$ While corporate media outlets continue to disguise American misconduct as acts of generosity, the reality of things in Africa remain under wraps.

The history textbooks fail to introduce America's global reach, missing an opportunity to help students understand how and why other nations and 
Secrecy and Society, Vol. 2, No. 2 [2021], Art. 4

peoples view the US the way they do. Nonetheless, competition with China is mentioned in select ways that ignore the global presence of the US. For example, in America Past and Present, China is discussed in terms of trade, but not regarding any competition with the US to control global resources. They also talk Trump's rhetoric toward China, but it is not grounded in any context regarding global resource control or ongoing neocolonial exploits. Similarly, Out of Many talks about China in the context of immigration and Trump's rhetoric. China is only mentioned briefly in the 1970s, then again regarding Tiananmen Square, nothing on African resources. Lastly, Unfinished Nation does note a US/China economic rivalry, and that US companies were moving to Mexico and China for cheap labor, but not much about geopolitics (other than relating the matter to North Korea).

\section{Conclusion}

Our findings reveal similar narratives in the corporate press and history textbooks. Future research is needed to determine why this is the case and what impact, if any, news literacy education might have on history graduates. One area to begin this research is with the authors of Out of Many. Much of their analysis went beyond corporate media narratives. Figuring out why and how they made those decisions where others did not could indicate where news literacy is an important component of more effective history degree programs.

Our research also found that the dominant history textbook narratives 
Higdon et al.: Today's Fake News is Tomorrow's Fake History

seem to share an ideology with the corporate press, one that utilizes an

exceptionalist mythological interpretation of the US. Indeed, the lives and experiences of non-American citizens and their countries were treated as background characters to the American story. The supposed successes of American leaders and the military were lauded while abuses and atrocities were concealed or dismissed. A US-centric interpretation of events was also visible in the textbooks with the use of labels such as "terrorism," and "tyrant," as well as the description of the US "owning" Iraq. These choices demonstrate a nationalist and politically charged bias in need of deeper investigation. Future research should be conducted to determine if patriotic narratives have any relation to the news habits of the historians.

Our research indicates the need for additional research about news literacy pedagogy in history programs. This brief study is a reminder that such work is ongoing and must be built upon those who came before us, who provided theoretical structure and empirical evidence as a foundation. It indicates that we need critical media literacy to ground historical research methodology in the present. This will be necessary as we further contend with the ongoing challenges of how today's fake news may become tomorrow's fake history, and how yesterday's fake history may misinform today's breaking news.

\section{Notes}

1. Address to a Joint Session of Congress and the American People en Español, United 
Secrecy and Society, Vol. 2, No. 2 [2021], Art. 4

States Capitol Washington, DC. https://georgewbushwhitehouse.archives.gov/news/releases/2001/09/20010920-8.html

2. Joseph Masco, "Sensitive But Unclassified: Secrecy and the Counterterrorist State," Public Culture 22, no. 3 (2010): 433-463; Susan Maret, "Introduction: Government Secrecy," In Government Secrecy, ed. Susan Maret (Emerald Group Publishing Limited, 2011), xi-xxx.

3. Yamuna Sangarasivam, "Cyber Rebellion: Bradley Manning, WikiLeaks, and the Struggle to Break the Power of Secrecy in the Global War on Terror," Perspectives on Global Development and Technology 12, no. 1-2 (2013): 69-79; George R. Lucas, "NSA Management Directive\# 424: Secrecy and Privacy in the Aftermath of Edward Snowden," Ethics \& International Affairs 28, no. 1 (2014): 29-38.

4. Susan Maret and Jan Goldman, Government Secrecy: Classic and Contemporary Readings, (Westport, CT: Libraries Unlimited, 2008).

5. Matthew Potolsky, The National Security Sublime: On the Aesthetics of Government Secrecy, (New York: Routledge, 2019).

6. Mark Crispin Miller, Cruel and Unusual: Bush/Cheney's New World Order, (New York: WW Norton \& Company, 2004); for more on corporate and establishment media labels, see Peter Phillips, How Mainstream Media Evolved into Corporate Media: A Project Censored History, Project Censored, February 7, 2019, https://www.projectcensored.org/howmainstream-media-evolved-into-corporate-media-a-project-censored-history/

7. Judith Miller, "Illicit Arms Kept Till Eve of War, an Iraqi Scientist Is Said to Assert," New York Times, April 21, 2003, https://www.nytimes.com/2003/04/21/world/aftereffectsprohibited-weapons-illicit-arms-kept-till-eve-war-iraqi-scientist.html: Editors, "The Times and Iraq: A Sample of the Coverage," New York Times,

https://archive.nytimes.com/www.nytimes.com/ref/international/middleeast/20040526CRIT IQUE.html; Russ Baker, "'Scoops' and Truth at the Times What Happens When Pentagon Objectives and Journalists' Needs Coincide," The Nation, June 5, 2003

https://www.thenation.com/article/scoops-and-truth-times/; Ed Pilkington, Helen Pidd, \& Martin Chulov, "Colin Powell Demands Answers Over Curveball's WMD Lies," The Guardian, February 16, 2011, https://www.theguardian.com/world/2011/feb/16/colin-powell-ciacurveball

8. David Barstow, "Message Machine: Behind Analysts, the Pentagon's Hidden Hand," April 20, 2008, New York Times, https://www.nytimes.com/2008/04/20/us/20generals.html

9. C. Wright Mills, The Power Elite, (New York: Oxford University Press, 1956, 2000);Peter Phillips, Giants: The Global Power Elite, (New York: Seven Stories Press,) 2018; William Domhoff, Who Rules America?: Challenges to Corporate and Class Dominance, (New York: McGraw Hill Higher Education, 2010); Edward S. Herman And Noam Chomsky, Manufacturing Consent: The Political Economy Of The Mass Media, (New York: Random House, 1988, 2010); Chalmers Johnson, "Blowback," The Nation, September 27, 2001, https://www.thenation.com/article/archive/blowback/

10. Ralph McGehee, "The CIA and the White Paper on El Salvador," The Nation, April 11, 1981, later published in Covert Action Quarterly, Fall 1990, http://www.thirdworldtraveler.com/CIA/McGehee CIA Indo.html 
Higdon et al.: Today's Fake News is Tomorrow's Fake History

11. Nolan Higdon, The Anatomy of Fake News: A Critical News Education, (Oakland, California: University of California Press, 2020), 9.

12. Nancy Snow, "Terrorism, Public Relations, and Propaganda," Anandam P. Kavoori and Todd Fraley (eds), Media, Terrorism, and Theory: A Reader (New York: Rowan and Littlefield, 2006), 146.

13. Higdon, The Anatomy of Fake News.

14. Ibid.

15. Higdon, The Anatomy of Fake News; Stanford History Education Group, Evaluating Information: The Cornerstone of Civic Online Reasoning, Stanford University, November 22, 2016 , https://stacks.stanford.edu/file/druid:fv751yt5934/SHEG\%20Evaluating\%20Information\%2 0Online.pdf; Sarah McGrew et al. Can students evaluate online sources? Learning from assessments of civic online reasoning," Theory \& Research in Social Education 46, no. 2 (2018): 165-193. https://doi.org/10.1080/00933104.2017.1416320; Andrew Guess, Jonathan Nagler, and Joshua Tucker, "Less than you think: Prevalence and predictors of fake news dissemination on Facebook,"Science Advances 5, no. 1 (2019): https://doi.org/10.1126/sciadv.aau4586

16. Ogheneakpobor Williams Atu, "Teaching History As A Science: A Reflection On The Principles Of Scientific Study," Teaching History 1, no. 6 (2019), 71.

17. Anna Green and Kathleen Troup, eds. The Houses of History: A Critical Reader in Twentieth-century History and Theory, (Manchester, U.K.: Manchester University Press, 1999).

18. Geoffrey Barraclough, An Introduction to Contemporary History, (London: Penguin Publishing, 1967).

19. Jack Shafer, "Who Said it First?" Slate, August 30, 2010, https://slate.com/news-andpolitics/2010/08/on-the-trail-of-the-question-who-first-said-or-wrote-that-journalism-isthe-first-rough-draft-of-history.html

20. Arthur Schlesinger, Jr., "On The Writing Of Contemporary History," The Atlantic, March 1967, https://www.theatlantic.com/magazine/archive/1967/03/on-the-writing-ofcontemporary-history/305731/

21. Jo Guldi, And David Armitage, The History Manifesto (Cambridge University Press, 2014).

22. Cahal Milmo, "Young Historians 'Are Damaging Academia' In Their Bid For Stardom," May 9, 2012, The Independent, https://www.independent.co.uk/life-style/history/younghistorians-are-damaging-academia-their-bid-stardom-7723284.html

23. Higdon, The Anatomy of Fake News.

24. Ibid.

25. Ibid.

26. Ibid.

27. Ibid. 
28. Herbert Blumer, Symbolic Interactionism: Perspective And Method (Upper Saddle River, New Jersey: Prentice-Hall, 1969).

29. Marshall McLuhan, Understanding Media: The Extensions of Man (New York: Mentor Press, 1964); Neil Postman, Teaching As A Conserving Activity (New York: Delacorte Press, 1979); Lance Strate, Media Ecology, Communication Research Trends 23, No. 2 (2004): 148.

30. Niall P. Stephens, "Toward A More Substantive Media Ecology: Postman's Metaphor Versus Posthuman Futures," International Journal Of Communication 8 (2014): 19.

31. Marshall McLuhan, Quentin Fiore, And Jerome Agel, The Medium Is The Message With Marshall McLuhan (San Francisco: Hardwired, 1967); Marshall McLuhan, Gutenberg Galaxy, The Making Of Typographic Man (Toronto, Canada: University Of Toronto Press, 1962).

32. Paul Heyer, Communications And History: Theories Of Media, Knowledge, And Civilization (New York, New York: Greenwood Press, 1988); Graeme Patterson, History And Communications: Harold Innis, Marshall McLuhan, And The Interpretation Of History (Toronto, Canada: University Of Toronto Press, 1990); Judith Stamps, Unthinking Modernity: Innis, McLuhan, And The Frankfurt School (Montreal \& Kingston: Mcgill-Queens University Press, 2001).

33. Michael Kelly, Michel Foucault, And Jürgen Habermas, Eds., Critique And Power: Recasting The Foucault/Habermas Debate (Cambridge, Massachusetts: MIT University Press, 1994); Max Horkheimer, Critical Theory Selected Essays (New York: Continuum Publishing, 1982); Paul Piccone, The Essential Frankfurt School Reader (New York, New York: Continuum Press, 1978).

34. Ibid; Stuart Hall, Dorothy Hobson, Andrew Lowe, And Paul Willis, Eds., Culture, Media, Language: Working Papers In Cultural Studies, 1972-79 (New York, New York, Routledge, 2003).

35. All of the Top Censored Stories lists dating back to 1976 are available at Project Censored's website, https://www.projectcensored.org/top-25-censored-stories-of-all-time/. For more up to date information, see their most recent annual book, Mickey Huff and Andy Lee Roth, eds., Censored 2020: Through the Looking Glass, (New York: Seven Stories Press, 2019). All of the following citations from the Censored annual books from endnote 38 on, are online at projectcensored.org. The citations allude to the online presence of the independent news stories included. The names listed in citations here are to the faculty evaluator and student researchers of the story summaries and analysis, not the original independent articles/journalists themselves. For that information, see the links provided as all original sources are listed at the Project Censored website. For more on censorship and issues around government secrecy, see Research in Social Problems and Public Policy, Volume 19, Government Secrecy, Susan Maret, ed., (United Kingdom: Emerald Publishing, 2011), in that volume, specifically see Peter Phillips and Mickey Huff, "Project Censored International: Colleges and Universities Validate Independent News and Challenge Global Media Censorship," pp. 153-169.

36. James W. Loewen, Lies My Teacher Told Me: Everything Your American History Textbook Got Wrong (New York: The New Press, 1995, [2008, 2018]).

37. American Textbook Council, 2018, Widely Adopted History Textbooks, https://historytextbooks.net/adopted.htm 
Higdon et al:: Today's Fake News is Tomorrow's Fake History

38. Cassie Cypher, Shannon Arthur, James Carr, and Alexandra Von Meier, Secrets of Cheney's Energy Task Force Come to Light, Project Censored, April 29, 2010, https://www.projectcensored.org/8-secrets-of-cheneys-energy-task-force-come-to-light/

39. Peter Philips, James F. Tracy, Brooks Brorsen, and Alison Gorrell, Media Whitewash Senate's CIA Torture Report, Project Censored, October 6, 2015, https://www.projectcensored.org/17-media-whitewash-senates-cia-torture-report/

40. Ibid.

41. Heidi LaMoreaux, Danielle Stanton, Tim LeDonne, and Kat Pat Crespan, Over One Million Iraqi Deaths Caused by US Occupation, Project Censored, April 30, 2010, https://www.projectcensored.org/1-over-one-million-iraqi-deaths-caused-by-us-occupation/

42. Ibid.

43. Nathan Guzik, Jennifer Mathis, Jennifer Acio, and Phil Beard, The US and NATO Deliberately Started the War with Yugoslavia, Project Censored, April 30, 2010, https://www.projectcensored.org/10-the-us-and-nato-deliberately-started-the-war-withyugoslavia/

44. Austin Hamilton, Elliot D. Cohen, and Mickey Huff, CIA Warned Bush Administration of Terrorist Attack Prior to 9/11, Project Censored, October 4, 2016, https://www.projectcensored.org/11-cia-warned-bush-administration-terrorist-attack-prior$\underline{911 /}$

45. Ibid.

46. Molly Lipinski, Meghan Brandts, and Julie Andrzejewski, Obama Cuts Domestic Spending and Increases Military Corporate Welfare, Project Censored, October 2, 2010, https://www.projectcensored.org/13-obama-cuts-domestic-spending-and-increasesmilitary-corporate-welfare/

47. Ibid.

48. Ibid.

49. Ned Patterson, Tony White, and Craig Winston, US Uses Tsunami to Military Advantage in Southeast Asia, Project Censored, April 29, 2010, https://www.projectcensored.org/5-ususes-tsunami-to-military-advantage-in-southeast-asia/

50. Adrienne Smith, Sarah Kintz, and Jorge Porras, US Uses South American Military Bases to Expand Control of the Region, Project Censored, April 29, 2010, https://www.projectcensored.org/17-us-uses-south-american-military-bases-to-expandcontrol-of-the-region/

51. Ibid.

52. Ioana Lupu and Marco Calavita, AFRICOM: US Military Control of Africa's Resources, Project Censored, April 28, 2010, https://www.projectcensored.org/3-africom-us-militarycontrol-of-africas-resources/

53. Ibid. 